\title{
GENETIC POLYMORPHISM OF OROSOMUCOID (ORM) IN POPULATIONS OF THE UNITED KINGDOM, INDIAN SUBCONTINENT, AND CAMBODIA
}

\author{
S.S. Mastana, ${ }^{1}$ R. Jayasekara, ${ }^{2}$ P. Fisher,${ }^{1}$ \\ R.J. SOKOL, ${ }^{3}$ and S.S. PAPIHA ${ }^{4, *}$ \\ ${ }^{1}$ Human Genetics Laboratory, Department of Human Sciences, Loughborough University, \\ Loughborough, UK \\ ${ }^{2}$ Human Genetics Unit, Faculty of Medicine, University of Colombo, \\ Colombo, Sri Lanka \\ ${ }^{3}$ Regional Blood Transfusion Centre, \\ Longley lane, Sheffield, UK \\ ${ }^{4}$ Department of Human Genetics, University of Newcastle upon Tyne, \\ 19/20 Claremont Place, Newcastle upon Tyne, UK
}

\begin{abstract}
Summary The genetic variation of the human serum orosomucoid (ORM) was investigated by isoelectric focusing (IEF) followed by immunofixation in 15 different populations from East Midlands (United Kingdom), India, Sri Lanka, and Cambodia. Statistically significant differences were observed between various Asiatic and British populations, however differences within Asiatic and European populations were minor. The distribution of $O R M I$ alleles in populations investigated to date suggests an interesting east-west geographical cline. There is a suggestion that present day wide polymorphism at the ORM1 locus may be influenced by selection.
\end{abstract}

Key Words polymorphism, orosomucoid, ethnic groups, United Kingdom, India, Cambodia, Sri Lanka

\section{INTRODUCTION}

Orosomucoid (ORM), or alpha-1-acid glycoprotein, is an acute-phase reactant protein ( $\mathrm{mol} \mathrm{wt} \mathrm{40,000)}$ present in the human serum at levels between 0.5 and 1 $\mathrm{mg} / \mathrm{ml}$. Its serum concentration increases in the inflammatory response in number of diseases and in pregnancy (Schmid, 1976). Though its biological function is still obscure, it seems to play a role in inhibiting erythrocyte invasion by the malarial parasite and therefore preventing parasite increase and reducing their survival

Received March 8, 1993; Revised version accepted June 3, 1993.

*To whom correspondence should be addressed. 
(Freidman, 1983). The genetic polymorphism of ORM was first reported by Tokita and Schmid (1963) using starch gel electrophoresis. Subsequently, Johnson et al. (1969) described three different phenotypes using immunofixation which are the expression of two codominant alleles $O R M^{*} F$ and $O R M^{*} S$ at a single locus. Recent studies using isoelectric focusing have shown further heterogeneity in ORM. It has been established that ORM is coded by two loci, ORM1 and ORM2 (Yuasa et al., 1986; Weidinger et al.,1987) which are closely linked on chromosome 9 near $\mathrm{ABO}$ and AK1 systems (Eiberg et al., 1982).

The ORMI locus is polymorphic in most populations investigated with three common alieles $\left(O R M 1^{*} F\right\}$ or $O R M 1^{*} 1, O R M 1^{*} F 2$ or $\left.O R M\right)^{* 3}$, and $O R M I^{*} S$ or $O R M I^{* 2}$ ) (Escallon et al., 1987; Thymann and Weidinger, 1988; Yuasa et al., 1987). Several rare alleles have also been found a few being common in certain geographical regions, $O R M 2$ is polymorphic in the U.S. blacks (Escallon et al., 1987) and the Mongoloid populations (Yuasa et al., 1987), while in the Europe it is practically monomorphic (Yuasa et al., 1986). The ORM polymorphism has also been proven useful in the forensic characterisation of human and animal blood and semen stains (Harada et al., 1989; Yuasa et al., 1990a). So far the ORM genetic polymorphism has not been investigated extensively in several different regions of the world. The aim of this study was to increase our understanding of the ORM distribution by analysing population samples from four geographical regions of the East Midlands (Britain), ten endogamous and ethnjc populations from Western India, and Sri Lanka and the population of Khmer from Cambodia.

\section{MATERIALS AND METHODS}

Sera from a total of 1,581 healthy and unrelated individuals were collected as part of various genetic surveys. The samples belonged to the native residents of the four geographical regions of Britain, northwest Derbyshire (105), northeast Derbyshire (105), south Derbyshire (242), and Leicestershire (103); five endogamous groups of India, Brahmins (119), Marathas (140), Gujarati Hindu (84), Parsee (53), and Andhra Pradesh Hindus (115); five ethnic groups of Sri Lanka Sinhalese (88), Tamils (100), Burghers (100), Moors (98) and Malays (99), and Khmers of Cambodia (31). Serum samples were stored at $-20^{\circ} \mathrm{C}$ before use and tested within one year. Desialyzation of serum samples was performed by mixing $20 \mu \mathrm{l}$ neuraminidase (Sigma) ( $1 \mathrm{U} / \mathrm{ml}, \mathrm{pH} \mathrm{5.5)}$ to $5 \mu$ l of serum followed by incubation of the mixture overnight at $37^{\circ} \mathrm{C}$. ORM typing of neuraminidase treated plasma samples was carried out according to Yuasa et al. $(1986,1987)$ using 5\% Ampholine 4.5-5.4 (Pharmacia-LKB, Bromma, Sweden).

\section{RESULTS AND DISCUSSION}

The distribution of observed and expected phenotype numbers of the ORMI system in 15 populations studied is given in Table 1. All the populations investi- 


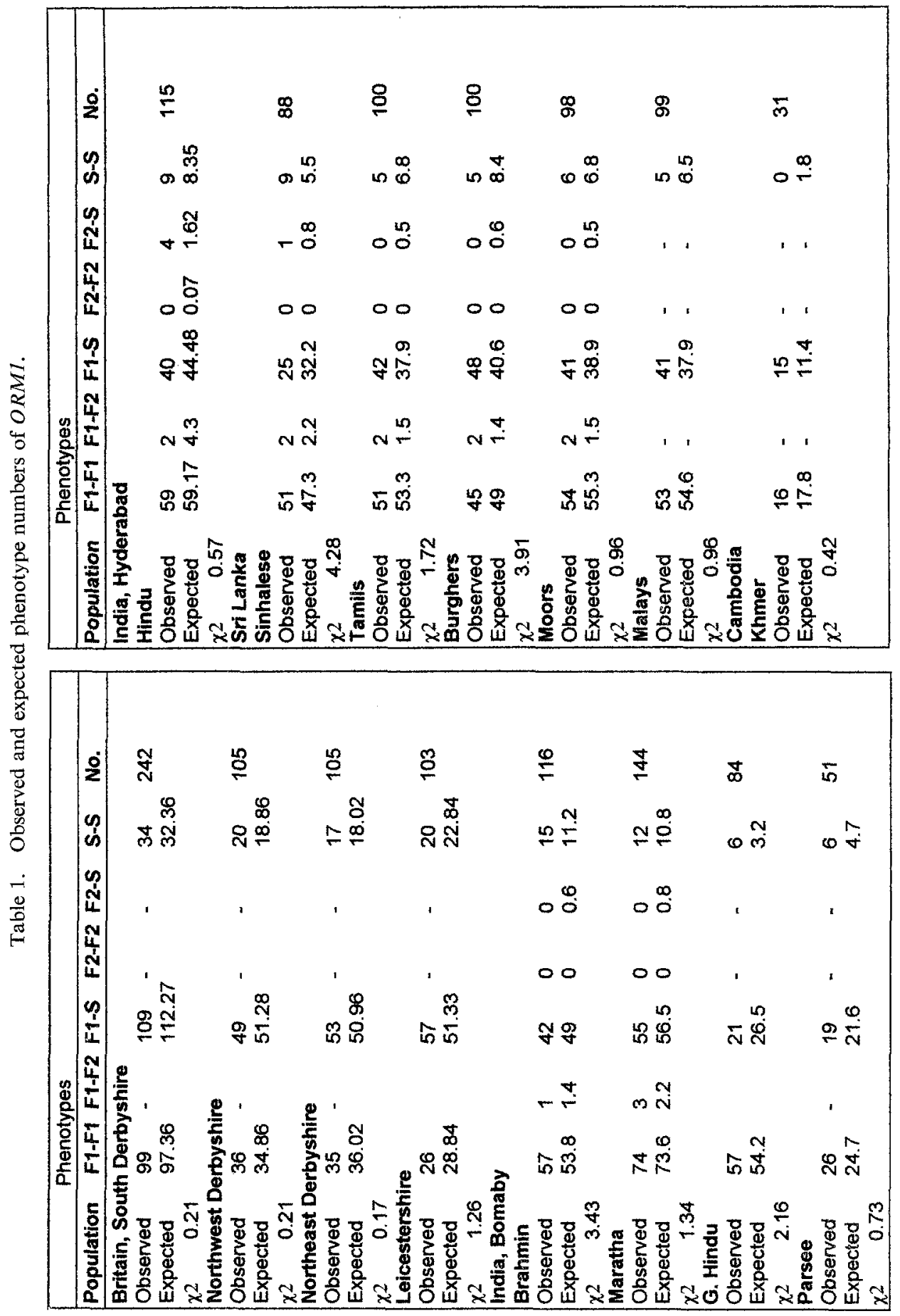

Vol. 38, No. 3, 1993 
Tabie 2. ORMI allele frequencies in different populations.

\begin{tabular}{|c|c|c|c|c|c|}
\hline Population & No. & ORM1*F1 & ORM1*F2 & ORM1*S & Reference \\
\hline \multicolumn{6}{|l|}{ Americas } \\
\hline Us Whites & 228 & 0.559 & - & 0.386 & - Escallon et al.1987 \\
\hline US Blacks & 181 & 0.619 & - & 0.384 & - Escallon et al.1987 \\
\hline Candian Indians & 169 & 0.547 & - & 0.453 & - Escallon et al.1987 \\
\hline Paraguayan & 200 & 0.645 & 0.023 & 0.307 & 0.025 Umetsu et al. (1989) \\
\hline \multicolumn{6}{|l|}{ United Kingdom } \\
\hline South Derbyshire & 242 & 0.634 & - & 0.366 & - This study \\
\hline Northwest Derbyshire & 105 & 0.576 & - & 0.424 & - This study \\
\hline Northeast Derbyshire & 105 & 0.586 & - & 0.414 & - This study \\
\hline Leicestershire & 103 & 0.529 & - & 0.471 & - This study \\
\hline Danes & 215 & 0.581 & 0.033 & 0.386 & - Thymann and Eiberg, (1986) \\
\hline \multicolumn{6}{|l|}{ Germans } \\
\hline West Germany & 670 & 0.627 & m & 0.373 & - Metzner and Schiel (1988) \\
\hline Munchen & 272 & 0.610 & 0.040 & 0.348 & 0.002 Weidinger et al. (1987) \\
\hline South Germany & 696 & 0.613 & 0.034 & 0.353 & 0.001 Thymann and Eiberg (1986) \\
\hline Swiss & 329 & 0.593 & 0.001 & 0.404 & 0.002 Eap et al. (1988) \\
\hline Switzerland & 220 & 0.607 & - & 0.393 & - Metzner and Scheil (1988) \\
\hline French & 112 & 0.563 & 0.049 & 0.388 & - Yuasa et al. (1986) \\
\hline \multicolumn{6}{|l|}{ Spanish } \\
\hline Basque & 150 & 0.573 & 0.033 & 0.393 & - Montiel et al. (1990) \\
\hline Galicia & 880 & 0.557 & 0.033 & 0.406 & 0.003 Montiel et al. (1990) \\
\hline Madrid & 315 & 0.621 & 0.005 & 0.375 & - Alonso et al. (1990) \\
\hline $\begin{array}{l}\text { Portuguese } \\
\text { Italy }\end{array}$ & 260 & 0.552 & 0.031 & 0.415 & 0.002 Montiel et al. (1990) \\
\hline Mainland italy & 567 & 0.621 & - & 0.379 & - Scacchi et al. (1992) \\
\hline Sardinia & 244 & 0.564 & - & 0.436 & - Scacchi et al, (1992) \\
\hline Lombardy & 600 & 0.599 & 0.015 & 0.386 & - Cerri and De Ferrari (1992) \\
\hline Libyans & 105 & 0.650 & 0.009 & 0.309 & 0.032 Sebetan and Sagisaka (1988) \\
\hline \multicolumn{6}{|l|}{ India } \\
\hline Brahmin & $1 \uparrow 6$ & 0.681 & 0.009 & 0.310 & This study \\
\hline Maratha & 144 & 0.715 & 0.011 & 0.274 & This study \\
\hline G. Hindu & 84 & 0.804 & - & 0.196 & - This study \\
\hline Parsee & 51 & 0.696 & - & 0.304 & - This study \\
\hline Hyderabad Hindus & 115 & 0.717 & 0.026 & 0.270 & - This study \\
\hline Parsees & 180 & 0.636 & 0.008 & 0.356 & - Saha et al. (1992) \\
\hline \multicolumn{6}{|l|}{ Sri Lanka } \\
\hline Sinhalese & 88 & 0.733 & 0.017 & 0.250 & - This study \\
\hline Tamils & 100 & 0,730 & 0.010 & 0.260 & - This study \\
\hline Burghers & 100 & 0.700 & 0.010 & 0.290 & - This study \\
\hline Moors & 98 & 0.733 & - & 0.257 & - This study \\
\hline Malays & 99 & 0.742 & - & 0.258 & - This study \\
\hline Sri Lankans & 140 & 0.700 & - & 0.268 & 0.033 Umetsu et al. (1989) \\
\hline Nepalese & 141 & 0.674 & 0.014 & 0.312 & - Yuasa et ał. (1986) \\
\hline \multicolumn{6}{|l|}{ China } \\
\hline Chinese & $\uparrow 63$ & 0.756 & - & 0.141 & 0.104 Yuasa et al . (1990a) \\
\hline Han Chinese & 286 & 0.703 & 0.021 & 0.276 & Yiping et al. (1992) \\
\hline Taiwanese & 200 & 0.726 & - & 0.181 & 0.094 Umetsu et al.(1988a) \\
\hline Cambodia & 31 & 0.758 & - & 0.242 & This study \\
\hline Filipinos & 115 & 0.790 & - & 0.169 & 0.041 Umetsu et al. $(1988 \mathrm{~b})$ \\
\hline \multicolumn{6}{|l|}{ Japanese } \\
\hline Yamagata & 500 & 0.779 & - & 0.221 & - Umetsu et al. (1985) \\
\hline Yamaguchi & 200 & 0.680 & 0.022 & 0.163 & 0.135 Yuasa et al. (1990b) \\
\hline Okinawa & 364 & 0.688 & - & 0.166 & 0.146 Yuasa et a!. (1990a) \\
\hline Myagi & 232 & 0.668 & 0.006 & 0.170 & 0.156 Sebetan and Sagisaka (1989) \\
\hline Thailand & 389 & 0.814 & - & 0.161 & 0.025 Umetsu et al. (1989) \\
\hline Cook Isianders & 318 & 0.789 & - & 0.211 & - Abe et al. (1988) \\
\hline Now Guinea & 110 & 0.841 & - & 0.159 & - Escallon et al. (1987) \\
\hline
\end{tabular}

Jpn J Human Genet 
gated were in Hardy-Weinberg equilibrium. The gene frequencies in populations investigated along with the $O R M 1$ frequencies collected from different studies are listed in Table 2.

The ORM2 locus was monomorphic in British population from East Midlands, Indians from Western India and Khmer from Cambodia, however the locus exhibited polymorphic variation in populations of Sri Lanka. The allele $O R M 2 * 4$ $(O R M 2 * L 7)$ was observed in all populations of Sri Lanka with frequency ranging from $1-2.5 \%$, however the allele $O R M 2 * 5(O R M 2 * H 6)$ was observed in three populations (Sinhalese, Tamils, and Malays) with frequencies between $0.5-2.2 \%$. The number of populations studied for this locus are very few; it is therefore difficult to comment if these alleles are the result of gene flow and admixture in the present day inhabitants of Sri Lanka.

The polymorphism on the $O R M I$ is more extensively studied. In the four regional samples of Britain the frequency of $O R M^{*} F 1$ allele was within the European range and there was no significant genetic heterogeneity among the four regional subpopulations of East Midlands $\left(\chi^{2}=9.57, \mathrm{df}=6, \mathrm{p}>0.05\right)$, but the phenotypic distribution in the two subpopulations, Leicestershire and south Derbyshire, was statistically significant $\left(\chi^{2}=7.82, \mathrm{df}=2, \mathrm{p}<0.05\right)$.

In the Indian subcontinent this is the first extensive study on ORM1 polymorphism. In different ethnic and endogamous groups of India and Sri Lanka, the lowest frequency of $O R M 1^{*} F 1$ was found in Indian Brahmins $(68 \%$ ) while the highest was found in Gujarati Hindus $(80 \%)$. The five ethnic groups of Sri Lanka show a very close range of $O R M 1 * R 1$ allele (70-74\%). The overall pattern of allele frequency variation in Sri Lanka is compatible with another study on Sri Lankans (Umetsu et al., 1989). The present Parsee $O R M 1^{*} F 1(70 \%)$ frequency is higher than observed in another sample (64\%) (Saha et al., 1992). This difference was statistically not significant. Overall the populations of Western Indian and Sri Lankan seems to be relatively homogenous except the Gujarati Hindus which differed significantly from Brahmins and Marathas of India $\left(\chi^{2}=7.06, \mathrm{df}=2, \mathrm{p}<\right.$ 0.05 and $\chi^{2}=6.17, \mathrm{df}=2, \mathrm{p}<0.05$, respectively) and from Tamils and Burghers $\left(\chi^{2}=6.39, \mathrm{df}=2, \mathrm{p}<0.05\right.$ and $\left.\chi^{2}=11.06, \mathrm{df}=2, \mathrm{p}<0.05\right)$ of Sri Lanka.

The $O R M 1^{*} F 1$ frequency in the Khmer population of Cambodia is $76 \%$, which fits well in the range observed for Indian subcontinent and other Mongoloid populations of the southeast Asia (Table 2).

Within the subpopulations from Britain, India, and Sri Lanka, there was no significant genetic diversity but the variation between the total British sample against each of total Indian and Sri Lankan samples was statistically highly significant (British vs. India $\chi^{2}=36.26, \mathrm{df}=2, \mathrm{p}<0.0001$ and British vs. Sri Lanka $\chi^{2}=43.46$, $\mathrm{df}=2, \mathrm{p}<0.0001$ ).

It has been observed from the Table 2 that in all the European populations the $O R M 1^{*} F 1$ gene is low and restricted around $60 \%$, and the $O R M 1^{*} 1 S$ gene may be as high as $47 \%$ averaging around $40 \%$. However the allele $O R M 1^{*} 1 F$ 


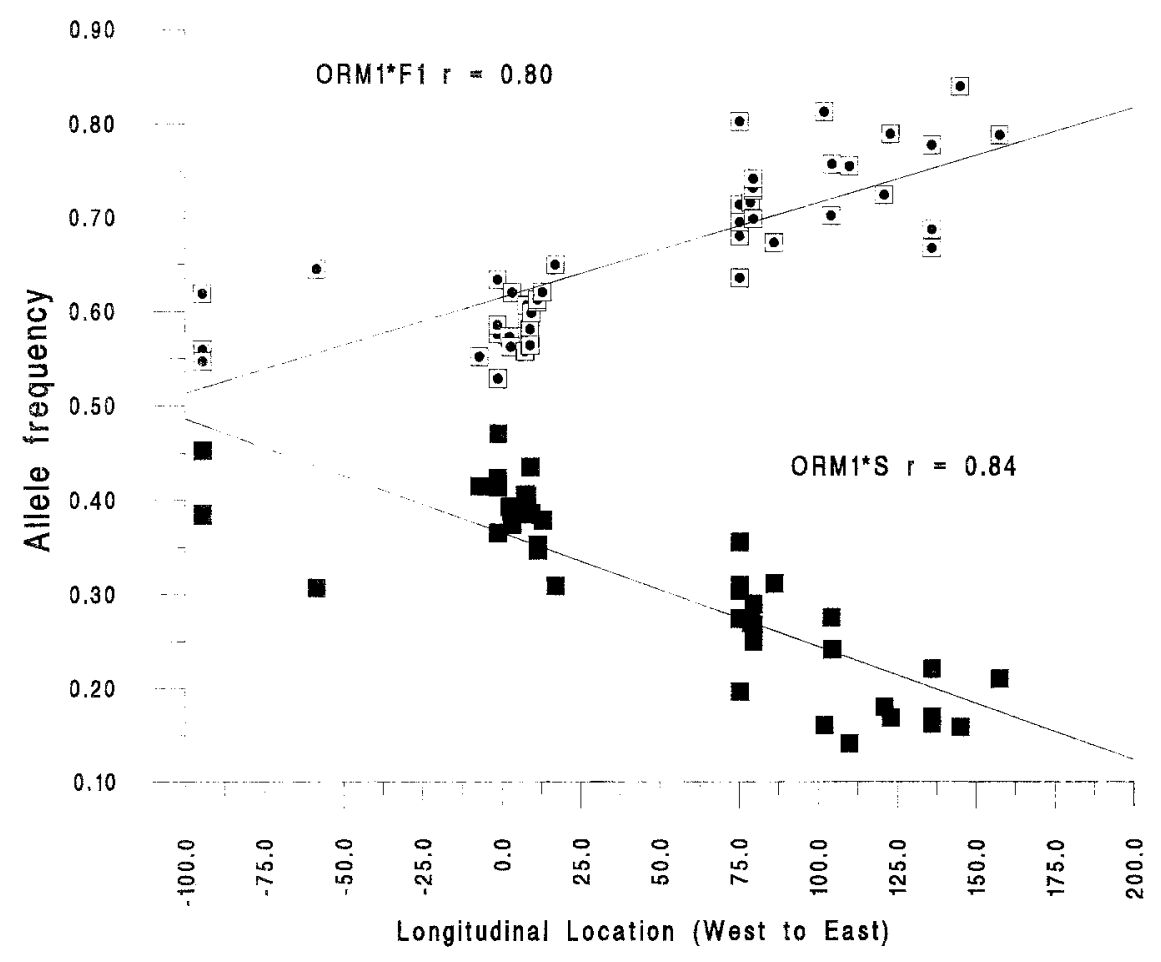

Fig. 1. Geographical cline of $O R M 1$ allele frequencies.

increases in central Asia and this increase continues towards the Southeast Asia, where the populations from Japan, Cambodia, Thailand, and Philippines give high value of $O R M 1^{*} F 1$ allele ranging between $69-81 \%$. The highest value of $O R M$ $1^{*} F 1$ so far reported is from New Guinea $(84 \%)$.

For 48 populations reported in the literature including this study, there is significant clinal increase of $O R M I^{*} F I$ allele frequency from west to east $(\mathrm{r}=0.8$, $\mathrm{p}<0.01)$. The $O R M I^{*} S$ allele frequency shows the opposite longitudinal trend $(\mathrm{r}=84, \mathrm{p}<0.01$ ) (Fig. 1).

In conclusion, the allele frequencies at the $O R M I$ locus show an interesting geographical distribution. At present, it is difficult to explain the observed clinal increase of $O R M I^{*} F I$ allele. More physiological data is needed to understand biological differences between the $O R M 1^{*} F 1$ and $O R M 1^{*} S$ alleles but it is possible that in addition to the gene flow and random drift the present day polymorphism of the $O R M I$ locus may significantly influenced by yet an unknown selection.

Acknowledgements We are most grateful to Mrs Sue Boam, Mrs. Margaret March, Mrs. Alice Pacynko and Mrs. Irene White for untiring help in collection and analysis of blood samples. 


\section{REFERENCES}

Abe S, Kurisaki E, Kuroda Y, Hiraiwa K (1988): Distribution of orosomucoid (ORMI) phenotypes in Cook Islanders: analysis by six band patterns. Gene Geog 2: 85-88

Alonso A, Visedo G, Sancho M, Fernandez-Piqueras J (1990): Isoelectric focusing in miniaturized gel: application to GC, Pi, Tf, and ORM subtyping in Central Spain. In: Polesky HF, Mayr WR (eds). Advances in forensic haemogenetics 3. Springer, Berlin, pp 255-259

Cerri N, DeFerrari F (1992): Genetic polymorphism of orosomucoid (ORMI and ORM2) in Lombardy (Italy). Int J Leg Med 104: 325-328

Eiberg H, Mohr J, Nielsen LS (1982): Linkage of orosomucoid (ORM) to ABO and AK1. Cytogenet Cell Genet 32: 272

Epp CB, Cuendet C, Baumann P (1988): Orosomucoid (alpha-1 acid glycoprotein) phenotyping by use of immobilized $\mathrm{pH}$ gradients with $8 \mathrm{M}$ urea and immunoblotting. A new variant encountered in a population study. Hum Genet 80: 183-185

Escallon MH, Ferrell RE, Kamboh MI (1987): Genetic studies of low abundance human plasma proteins. V. Evidence for a second orosomucoid structural locus (ORM2) expressed in plasma. Am J Hum Genet 41 : 418-427

Freidman MJ (1983): Control of malaria virulence by $\alpha 1$-acid glycoprotein (orosomucoid), an acutephase (inflammatory) reactant. Proc Natl Acad Sci USA 80: 5421-5424

Harada A, Umetsu K, Yuasa I, Ikeda N, Suzuki T (1989): Detection of orosomucoid 1 phenotypes in semen and semen stains. J Forensic Sci 34: 665-669

Johnson AM, Schmid K, Alper CA, Bisset L (1969): Inheritance of human $\alpha$ l-acid glycoprotein (orosomucoid) variants. J Clin Invest 48: 2293-2299

Metzner D, Scheil HG (1988): Polymorphism of human orosomucoid in populations of Western Germany and Switzerland. Gene Geog 2: 119-122

Montiel MD, Carracedo A, Blazquez-Caeiro JL, Andrade-Vide C (1990): Orosomucoid (ORMI and $O R M 2$ ) types in the Spanish Basque country, Galicia and northern Portugal. Hum Hered 40: $330-334$

Saha N, Undevia JV, Jumeja RK, Gahne B, Tay JSH (1992): Polymorphisms of alpha-1-acid (orosomucoid), alpha-2-HS glycoproteins and alpha-1B among the Parsis of India. Hum Hered 42: 367-371

Scacchi R, Corbo RM, Cossu G, Mureddu L, Mukas G, Pascone R (1992): Distribution of ORMI, $C 6, C 7$, and $A P O C-I I$ allele frequencies in populations from mainland Italy and Sardinia

Schmid K (1976): $\alpha$ 1-Acid glycoprotein. In: Putman FW (ed). The plasma proteins, Vol. 1. Academy, New York, pp 184-22.8

Sebetan IM, Sagisaka K (1988): Genetic polymorphism of orosomucoid ORMI and ORM2 in Libyans: occurrence of $O R M I^{*} 2.1$ and three new $O R M 2$ alleles. Jpn J Human Genet 33: 439 443

Sebetan IM, Sagisaka K (1989): Genetic polymorphisms of ORM1 and ORM2 in a Japanese population: occurrence of new $O R M I$ alleles. Z Rechtsmed 102: 5-9

Thymann M, Eiberg H (1986): Orosomucoid polymorphisms: determination by separator isoelectric focusing and demonstration of $O R M^{*} F$ subtypes. In: Brinkmann and Henningsen $\mathrm{K}$ (eds). Advances in forensic haemogenetics. 1, Springer-Verlag, Berlin

Thymann M, Weidinger S (1988): Subtyping of orosomucoid 1 (ORMI) by isoelectric focusing in agarose and polyacrylamide gels. Electrophoresis 9: 380-383

Tokita K, Schmid K (1963): Variation of $\alpha 1$ acid glycoprotein. Nature 200: 266-267

Umetsu K, Ikeda N, Kashimura S, Suzuki T (1985): Orosomucoid (ORM) typing by print lectinofixation: a new technique for isoelectric focusing. Two common alleles in Japan. Hum Genet 71: $223-224$

Vol. 38, No. 3, 1993 
Umetsu K, Yuasa I, Chen EG, Kudo T, Suzuki T (1988a): Orosomucoid I and orosomucoid 2 types in Taiwanese and Japanese: evidence for five new orosomucoid variants. Electrophoresis 9: $221-226$

Umetsu K, Yuasa I, Nishimura H, Sasaki H, Suzuki T (1988b): Genetic polymorphisms of orosomucoid and alpha-2-glycoprotein in a Philippine population. Hum Hered 38: 287-290

Umetsu K, Yuasa I, Yamashita T, Saito S, Yamaguchi T, Ellepola SB, Ishida T, Suzuki T (1989): Genetic polymorphisms of orosomucoid and alpha-2-HS glycoprotein in Thai, Sri Lankan and Paraguayan populations. Jpn J Human Genet 34: 195-202

Weidinger S, Muller T, Schwarzfischer F, Cleve H (1987): Three new orosomucoid (ORM) variants revealed by isoelectric focusing and print immunofixation. Hum Genet $77: 286-288$

Yping H, Qing G, Meiyun W (1992): Genetic polymorphism of alpha-2-HS-glycoprotein, group specific component and orosomucoid in the Han population, Chengdu, China. Hum Hered 42: $380-383$

Yuasa I, Umetsu K, Suenaga K, Robinet-Levy M (1986): Orosomucoid (ORM) typing by isoelectric focusing: evidence for two structural loci $O R M 1$ and $P R M 2$. Hum Genet 74: 160-161

Yuasa I, Suenaga K, Umetsu K, Ito K, Robinet-Levy M (1987): Orosomucoid (ORM) typing by isoelectric focusing: evidence for gene duplication of ORMI and genetic polymorphism of ORM2. Hum Genet $77: 255-258$

Yuasa I, Umetsu K, Nakayashiki N, Tamaki N, Shiono H, Okada K (1990a): Orosomucoid typing by isoelectric focusing: an improved method for ORM1 subtyping and reactivity of anti-human orosomucoid antibodies with animal orosomucoid. Proc First Intl Symposium. Advances in legal medicine, Kanazawa, 12-15 October 1990: 110

Yuasa I, Umetsu K, Suenaga K, Iha M, Hirata H, Ikebuchi J (1990b): Orosomucoid typing by isoelectric focusing: an analysis of ORM haplotypes. Hum Hered 40: 267-271 